\title{
Evaluation of genotoxicity and cytotoxicity amongst in dental surgeons and technicians by micronucleus assay
}

\author{
Molina Noyola Leonardo Daniel ${ }^{1,2}$, Coronado Romo María Eugenia ${ }^{3}$, Vázquez Alcaraz Silverio Jafet ${ }^{4}$, Izaguirre Pérez Marian Eliza ${ }^{1,2}$, \\ Arellano-García Evarista ${ }^{5}$, Flores-García Aurelio ${ }^{6}$ and Torres Bugarín Olivia ${ }^{1 *}$ \\ ${ }^{1}$ Laboratorio de Evaluación de Genotóxicos, Programa Internacional de Medicina, Universidad Autónoma de Guadalajara, Mexico \\ ${ }^{2}$ Facultad de Medicina, Universidad Autónoma de Guadalajara, Mexico \\ ${ }^{3}$ Departamento de Ortodoncia, Facultad de Odontología, Universidad Autónoma de Guadalajara, Mexico \\ ${ }^{4}$ Departamento de Endodoncia, Facultad de Odontología, Universidad Autónoma de Guadalajara, Mexico \\ ${ }^{5}$ Facultad de Ciencias, Universidad Autónoma de Baja California, Mexico \\ ${ }^{6}$ Unidad Académica de Medicina, Universidad Autónoma de Nayarit, Tepic, Nayarit, Mexico
}

\begin{abstract}
Introduction: Dental surgeons and technicians are continuously exposed to agents could be affect the genetic material and induce mutations. The aim of this study was to evaluate the genotoxic and cytotoxic occupational risk of dental surgeons and technicians through the micronucleated cells (MNC) and nuclear abnormalities (NA) assay in oral mucosa.

Methods: Case-control study. We have collected a buccal mucosa from dental surgeons, dental technicians and healthy individuals (matched by BMI, age and gender) The smears were fixed (ethanol 80\%/48 h), stained (orange acridine) and analyzed (microscope, 100×). The frequency of MNC and NA (binucleated cells [BNC], lobulated nucleus [LN], condensed chromatins [CC], karyorrhexis [KR], pyknosis (PN) and karyolysis [KL] were counted in 2,000 cells per participant.

Results: 90 samples were collected (26 surgeons, 19 technicians and 45 controls). Compared with controls, exception of PN, in surgeons was higher frequency and positive association of MNC and all NA ( $p<0.05)$. Technicians were higher frequency of MNC, BNC, CC, KR and CD $(p<0.05)$.

Conclusion: The dental surgeons and technicians have genotoxic and cytotoxic damage, demonstrated by MNC and NA, which are related to an increase risk of cancer, chronic degenerative diseases and premature aging. It is necessary to improve biosecurity actions and implement routine genotoxic risk detection methods.
\end{abstract}

Abbreviations: BNC: Binucleated cells (damage to cytokinesis); CC: Condensed chromatin; CD: Cell death $(\mathrm{CC}+\mathrm{KR}+\mathrm{KL})$; D-DNA: DNA damage (MNC+LN); KL: Karyolysis; KR: Karyorrhexis; MNC: Micronucleated cells; LN: Lobulated nucleus; PN: Pyknotic nucleus.

\section{Introduction}

The genetic integrity of numerous organisms, including humans, is compromised as a result of exposure to diverse potentially genotoxic; chemical, physical and biological agents. For this motive, it is important to determine the "tolerable" level of genetic damage and to implement trials that allow routine evaluation of this type of damage, in order to identify risk populations and enforce biosecurity actions [1]. For their part, dental surgeons and technicians have chronic exposure to agents that increase oxidative stress and could be danger to genetic material [2]. This materials can be ultraviolet light [2], x-rays, residual monomers [3], root canal sealer $[4,5]$, resin-based materials [6,7], zinc oxide-eugenol cement [2], hydrogen peroxide and beryllium [8].They are also exposed to materials with cytotoxic effects such as silver welding, copper, zinc, cadmium, nickel, triethylene glycol dimethacrylate (TEGDMA) and whitening gels [5-7,9]. Additional to the everyday innovation of dental materials with more sophisticated structural and therapeutic functions, which increases the need to supervise, foresee and/or control the possible threats [10]. Given this, supervising the genetic material damage in exposed populations is seen as a useful tool to prevent diseases which helps with the creation of new therapeutic targets [11]. The methods used to measure and predict clinical biological responses to dental materials are still controversial, confusing and to some extent, ineffective [10]. A well-accepted and reliable tool is the micronucleus detection technique (MN) and nuclear abnormalities technique (NA) in oral mucosa. This is a feasible, sensitive and universally valid trial with technological accessibility, useful to assess genetic instability $[10,12,13]$ which can be applied to tissues with a high rate of cell division like epithelia $[1,2]$, among them oral mucosa. The mucosa is a non-keratinized flat stratified epithelium, and may reflect the genotoxic effect that happened in cells of the basal layer, which will migrate to the superficial layer where they are exfoliated $[13,14]$.

MNs are whole chromosomes or fragments of chromosomes that are delayed during cell division and appear in the cytoplasm of daughter cells as an additional minor nucleus, smaller than the main nucleus

${ }^{*}$ Correspondence to: Olivia Torres Bugarín, Sistema Nacional de Investigadores II, Laboratorio de Evaluación de Genotóxicos, Programa Internacional de Medicina, Universidad Autónoma de Guadalajara, Av. Patria 1201, Lomas del Valle, Zapopan, Jalisco, México, E-mail: oliviatorres@hotmail.com

Key words: dental surgeons, dental technicians, genotoxicity, micronuclei, nuclear abnormalities, occupational risk

Received: March 23, 2019; Accepted: April 19, 2019; Published: April 23, 2019 
[11-13,15]; NAs are cells with a lobulated nucleus (LN), binucleated cells (BNC), condensed chromatin (CC), karyorrhexis (KR), pyknotic nucleus (PN) and karyolysis (KL). These are phenomena that can appear in anomalous process of cellular differentiation and are indicators of DNA damage; (D DNA), variations in cytokinesis (BNC) and cell death (CC, KR, PN and KL), the mechanism of development or the biological significance of each of these nuclear abnormalities is not completely explained so far, it has been associated with a sizeable number of chronic degenerative diseases, neoplasic progressions, premature aging, among others $[11,12,15-20]$. These phenomena can be identified by the criteria established by Tolbert and Thomas et al. [21-23]. The aim of this study was to evaluate the genotoxic and cytotoxic occupational risk of dental surgeons and technicians through the micronucleated cells (MNC) and nuclear abnormalities (NA) assay in oral mucosa.

\section{Material and methods}

\section{Study population}

Case-control study. We carried this study at January 2017 to February 2018. The study subjects were divided into 4 groups: 1) Dental surgeons $(n=26), 2)$ Control of dental surgeons $(n=26), 3)$ Dental technicians $(n=19)$, and 4) Control of dental technicians $(n=19)$; All participants worked in different dental labs in Guadalajara city Jalisco, Mexico. Dental surgeons and dental technicians had to have at least one year of labor in the area; the controls were defined as individuals not related to the profession, which were matched by age, sex and BMI, with apparently good health status and without habits of alcohol or tobacco. None suffered from chronic degenerative diseases and the intake of medications known as micro nucleogenic was ruled out. We excluded from the trial all insufficient or poor-quality samples and subjects who withdrew their consent.

\section{Sampling and sample processing}

Two samples of exfoliated epithelial cells of the oral mucosa of each participant were taken, these were obtained by a soft rubbing of the previously moistened cheek (cheek-swab). The smears were made on previously coded slides, dried at room temperature, fixed with $80 \%$ ethanol for 48 hours and stained with orange acridine base (SigmaAldrich 235474-25G Lot. \#MKBD5351V) in buffer phosphate (Sdium phosphate dibasic S5136-500G Sigma-Aldrich Lot. \# SLBN3067V; Sigma-Aldrich S9638-500G Lot. \# SLBN4713V). They were examined under the microscope (Carl Zeiss IVFL Axiostar Plus ${ }^{\circledR}$ equipped with fluorescence IVFL filters of 450-490 $\mathrm{nm}$ ) with $100 \times$ optical amplification (planacromatic, 1.25 oli) where 2,000 cells were examined per sample to quantify the frequency of cells with MNC or NA (LN, BNC, PN, CC, $\mathrm{KR}$ and $\mathrm{KL}$ ) (Figure 1).

\section{Data analysis}

We compared the variables (MNC, NA, age, gender, BMI, smoking, exposure time in years) of dental surgeons vs. control of dental surgeons and dental technicians vs. control of dental technicians, and an evaluation was made between dental surgeons and dental technicians. The Mann-Whitney $U$ was used for non-parametric variables and the t-student (Statistical significance test methods were $\mathrm{p}<0.05$ ) through the GraphPad Prism 7 program for the parametric ones. For the intra-group data association analysis, each of the at-risk populations was divided by age (years): $<25$ and $>25$ years; BMI $\left(\mathrm{Kg} / \mathrm{m}^{2}\right): 18.5-$ 24.9 and $>25$; working time (years): $<5$ and $>5$; smoking: positive and negative; Gender: male and female.

\section{Ethical consideration}

This study was registered in the Directorate of Research of the Autonomous University of Guadalajara (5-029-302-15-022), it was performed under the Mexican health laws established in PROY- NOM012-SSA3-2007 (DOF: 05-11-2009) and all the points established in the Federal Law for the Protection of Personal Data (DOF: 05-07-2010) were accomplished.

\section{Informed consent}

Each participant had a verbal explanation of the objectives and risks of the study, after which they signed an informed consent, in addition to responding a questionnaire to collect demographic information.

\section{Results}

90 samples of subjects between 18 and 68 years of age were gathered; 26 were from dental surgeons and 19 from dental technicians each with their respective control group, deprived of statistically significant differences in age, gender or BMI (Table 1). It should be noted that all subjects at risk in both populations, used the basic established biosecurity measures (copings, lenses, covers, gowns and gloves).

When analyzing the frequency of MNC and NA in dental surgeons, it was perceived that they report a higher frequency of nearly all of them compared to their respective controls $(p<.05)$ except in PN. The magnitude of association of the work of dental surgeons with the presence of each variable was inconstant, the one that obtained the highest degree of association was the presence of KR with an OR of 18.9 (2.5-210.3) $p<.02$ (Table 2, Figure 2). When analyzing the frequency of $\mathrm{MNC}$ and NA in dental technicians, higher frequency $(p<.05)$ of MNC, $\mathrm{BNC}, \mathrm{CC}, \mathrm{KR}$ and $\mathrm{CD}$ was discovered.

The degree of association of the work of dental technicians with the presence of each of these variables was inconstant, the only one that had
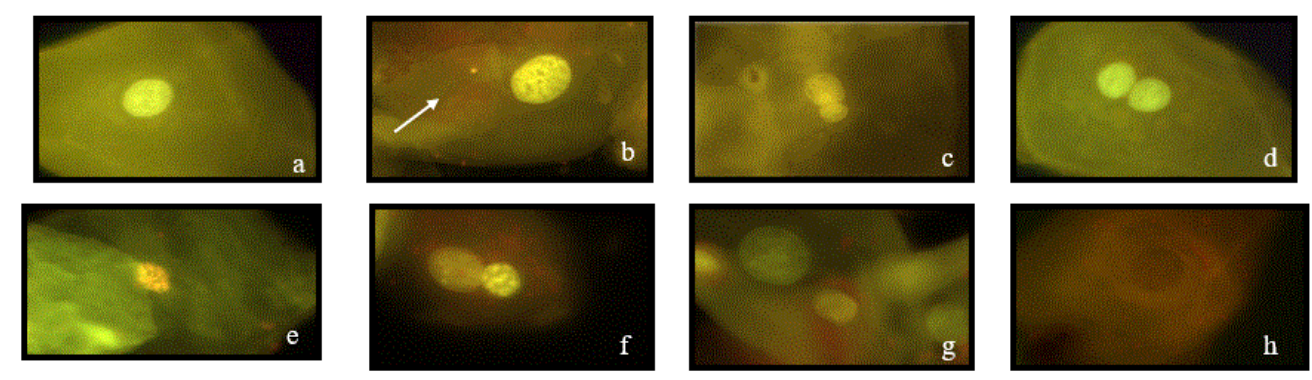

Figure 1. Microphotographs of MNi and NA, identified according to the HUMNxl scoring criteria. The figure shows a series of 8 microphotographs of oral mucosa cells stained with acridine orange at 100x optic amplification with a Carl Zeiss IVFL Axiostar Plus microscope, 450-490 nm fluorescencefilters. a) Normal buccal cell without any MNi or NA, b) A buccal cell with the presence of Micronucleus (CMN) (white arrow), c) a Lobed-nuclei cell (LN), d) a Binucleated cell (CBN), e) a, Karyorrhectic cell f) a Condensed-chromatin cell (CC), g) a Pyknotic cell (PN) and h) Karyolitic cell (KL) 
Table 1. Data of dental surgeons, dental technician and controls

\begin{tabular}{|c|c|c|c|c|c|c|}
\hline Variable & D. Surgeon & Control & (p-value) & D. Technician & Control & (p-value) \\
\hline Female n (\%) & $17(65.4)$ & $17(65.4)$ & NS & $6(31.6)$ & $6(31.6)$ & NS \\
\hline Age yr \pm sd* & $25.8 \pm 2.9$ & $25.6 \pm 5.4$ & $P=.8 ; t=.2$ & $28.4 \pm 13.8$ & $29.2 \pm 12.73$ & $p=.9 ; t=.06$ \\
\hline BMI Median (min-max) & $23.5(18.2-28.2)$ & $24.9(20.7-29.8)$ & $p=.1 ; t=95$ & $27.4(22.0-38.3)$ & $25.2(20.7-34.6)$ & $p=.07 ; \mathrm{t}=110$ \\
\hline Smock n $(\%)$ & $5(19.2)$ & 0 & NS & $3(15.8)$ & 0 & NS \\
\hline Work yr \pm sd* & $5.9 \pm 1.9$ & NS & NS & $5.6 \pm 2.3$ & NS & NS \\
\hline
\end{tabular}

D.: Dental; BMI: Body mass index; NS: Not significant; n: Sample size; *Data are expressed as mean \pm standard deviation, t-Student and U from Mann Whitney

Table 2. Micronucleated cells and nuclear abnormalities in dental surgeons and controls

\begin{tabular}{|c|c|c|c|c|}
\hline Variable & $\begin{array}{l}\text { Dental surgeons }(\mathrm{n}=26) \\
\text { Median (min-max) }\end{array}$ & $\begin{array}{c}\text { Controls (n=26) } \\
\text { Median (min-max) }\end{array}$ & $\begin{array}{c}\text { U from Mann Whitney } \\
(p \text {-value })\end{array}$ & Or ( $p$-value) \\
\hline $\mathrm{MNC}$ & $1.6(0-5)$ & $0.6(0-3)$ & T $210(0.003)^{*}$ & $9.3(0.05)^{*}$ \\
\hline LN & $5.8(1-18)$ & $2.6(0-8)$ & T $135.5(0.0004)^{*}$ & $3.9(0.4)$ \\
\hline D-DNA & $7.5(1-23)$ & $3.2(0-8)$ & T $128(0.0002)$ & $11.2(0.0001)$ \\
\hline $\mathrm{BNC}$ & $8.1(2-18)$ & $2.0(0-7)$ & T $53(0.0001)$ & $16(0.0001)$ \\
\hline $\mathrm{PN}$ & $0.8(1-3)$ & $1.6(0-5)$ & Т $225.5(0.07)$ & $0.0(0.05)$ \\
\hline $\mathrm{CC}$ & $3.4(0-12)$ & $0.7(0-5)$ & T $160(0.001)$ & $7.7(0.02)$ \\
\hline KR & $2.8(0-13)$ & $0.6(05)$ & T $144(0.0003)$ & $18.9(0.02)$ \\
\hline KL & $3.4(0-12)$ & $1.6(0-6)$ & T $188(0.01)$ & $1.7(0.5)$ \\
\hline $\mathrm{CD}$ & $10.4(0-30)$ & $4.5(0-12)$ & T $182(0.01)$ & $7.9(0.005)$ \\
\hline
\end{tabular}

Values reported in 2,000 cells, n: Sample size, MNC: Micronucleated cells, LN: Lobulated nucleus, D DNA: DNA damage (MNC+LN), BNC: Binucleated cells (damage to cytokinesis); PN: Pyknotic nucleus, CC: Condensed chromatin; KR: Karyorrhexis; KL: Karyolysis; CD: Cell death (CC+KR+KL).

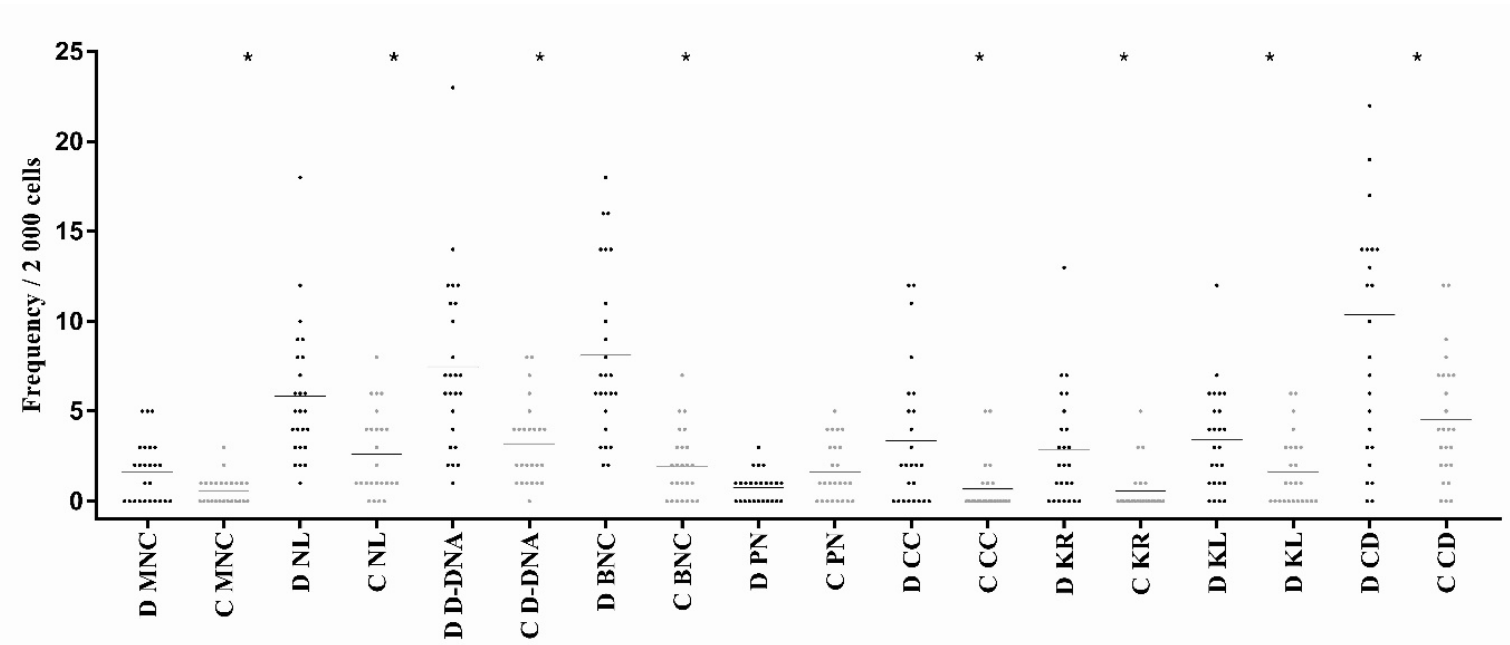

Figure 2. Dispersion of micronucleated cells and nuclear abnormalities in dental surgeons and controls (D: Dental surgeon; C: Control; MNC: Micronucleated cells; NL: Lobulated nucleus; D-DNA: DNA damage $(\mathrm{MNC}+\mathrm{LN})$, BNC: Binucleated cells (damage to cytokinesis); PN: Pyknotic nucleus; CC: Condensed chromatin; KR: Karyorrhexis; KL: Karyolysisand; CD: Cell death $\left.(\mathrm{CC}+\mathrm{KR}+\mathrm{KL}) ;{ }^{*} \mathrm{P}<0.05\right)$

statistical significance was when the D DNA was associated with an OR of $0.8(0.2-2.8) p=0.005$ (Table 3, Figure 3).

When comparing dental surgeons and dental technicians, an increase in the frequency of D DNA, BNC and PN was witnessed $(p<0.05)$ in the dental surgeons while the frequency of the LN was higher in dental technicians $(p<0.05)$. No associations or differences were found in the intragroup analysis of dental technicians or dental surgeons regarding the presence of $\mathrm{MNC}$ and NA. No differences were found when stratifying the respective groups in the variables of age, BMI, time of work, smoking and gender.

\section{Discussion}

It should be noted that genotoxic damage usually goes unnoticed, however, it produces a directly or indirectly effect on DNA and could be express as mutations with teratogenic or carcinogenic effect; the result is mostly catastrophic, since they put the organism's life at risk [3,11$15,24]$. The increase of oxidative stress and genotoxic damage has been described in dental patients as a result of exposure to different materials and procedures $[10,17,25,26]$. However, in dental-health professionals there are no studies in which this type of risk is evaluated, and it should be considered that dental surgeons and dental technicians are continuously exposed to mixtures of agents related dental procedures which can be physical, chemical and biological; for example, infective microorganisms [25,27], welding materials [11,26,28,29], $\mathrm{x}$-rays $[8,24,30]$, ultraviolet light $[31,32]$, acrylics, adhesives, and some more $[4,6,33]$. It is clear that these agents can produce health problems, increase of reactive oxygen species and damage to the genetic material; these phenomena have been associated with a higher risk of developing cancer, premature aging and multiple chronic degenerative diseases $[11,14,22,23,25-27,34,35]$.This study shows damage to the genetic material of both populations exposed to dental materials, where it 
Table 3. Micronucleated cells and nuclear abnormalities in dental technicians and controls

\begin{tabular}{|c|c|c|c|c|}
\hline Variable & $\begin{array}{l}\text { Dental technicians }(\mathrm{n}=19) \\
\text { Median (min-max) }\end{array}$ & $\begin{array}{c}\text { Controls (n=19) } \\
\text { Median (min-max) }\end{array}$ & $\begin{array}{c}\text { U from Mann Whitney } \\
(p \text {-value })\end{array}$ & $\begin{array}{c}\text { Or } \\
(p \text {-value })\end{array}$ \\
\hline $\mathrm{MNC}$ & $1.7(0-4)$ & $0.7(0-3)$ & T $106(0.04)$ & $8.3(0.08)$ \\
\hline LN & $2.7(1-5)$ & $3.9(0-6)$ & Т $132(0.2)$ & $0.4(0.99)$ \\
\hline D-DNA & $4.4(1-9)$ & $4.8(0-6)$ & T $165(0.7)$ & $0.8(0.005)$ \\
\hline $\mathrm{BNC}$ & $4.3(0-10)$ & $2.1(0-5)$ & T $85(0.004)$ & $11.69(0.3)$ \\
\hline $\mathrm{PN}$ & $1.7(0-4)$ & $4.2(0-5)$ & T $157(0.5)$ & $0.4(0.6)$ \\
\hline $\mathrm{CC}$ & $1.7(0-4)$ & $0.9(0-6)$ & Т $107.5(0.02)$ & $3.3(0.99)$ \\
\hline KR & $1.3(0-4)$ & $0.4(0-3)$ & T $86(0.002)$ & $2.1(0.99)$ \\
\hline $\mathrm{KL}$ & $2.1(0-5)$ & $2.6(0-8)$ & T $149(0.4)$ & $0.2(0.32)$ \\
\hline $\mathrm{CD}$ & $6.7(2-14)$ & $2.6(0-9)$ & Т $49(<0.0001)$ & $1.3(0.99)$ \\
\hline
\end{tabular}

Values reported in 2,000 cells, n: Sample size; MNC: Micronucleated cells; LN: Lobulated nucleus; D-DNA: DNA damage (MNC+LN); BNC: Binucleated cells (damage to cytokinesis); PN: Pyknotic nucleus; CC: Condensed chromatin; KR: Karyorrhexis; KL: Karyolysis; CD: Cell death (CC+KR+KL).

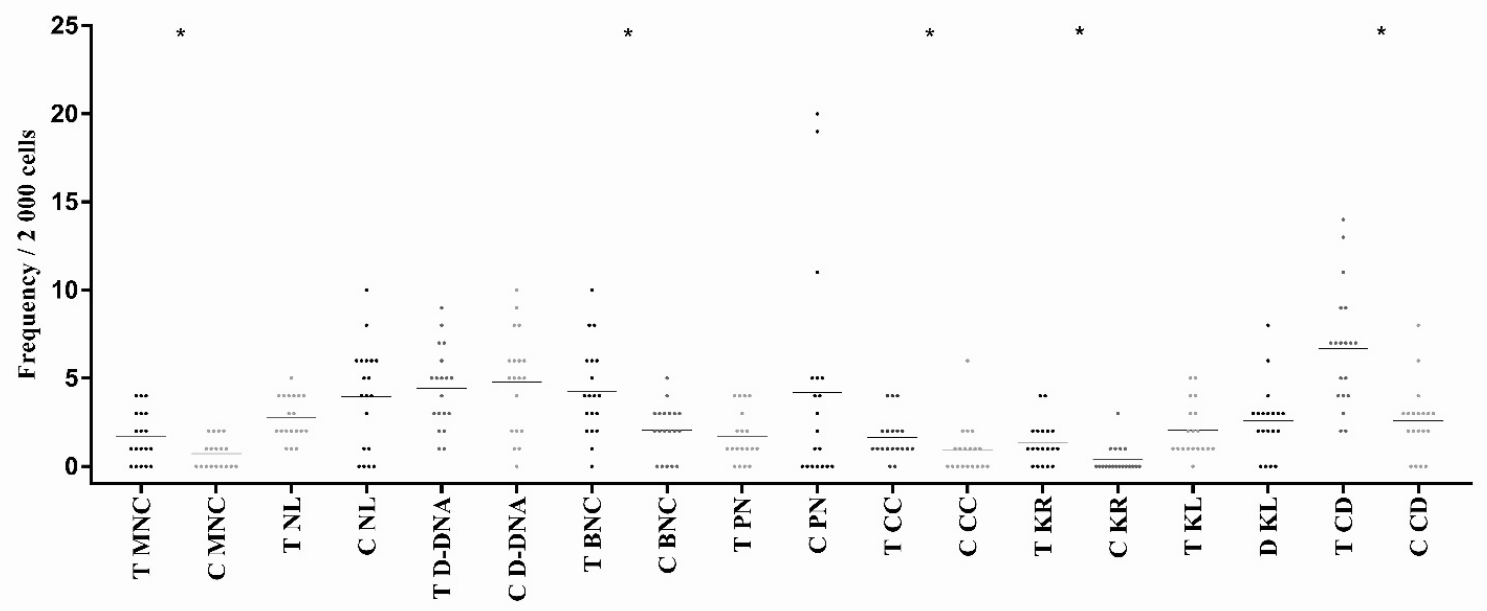

Figure 3. Dispersion of micronucleated cells and nuclear abnormalities in dental technicians and controls (T: Dental technicians; C: Control; MNC: Micronucleated cells; NL: Lobulated nucleus; D-DNA: DNA damage (MNC+LN); BNC: Binucleated cells (damage to cytokinesis); PN: Pyknotic nucleus; CC: Condensed chromatin; KR: Karyorrhexis; KL: Karyolysisand; CD: Cell death $\left.(\mathrm{CC}+\mathrm{KR}+\mathrm{KL}) ;{ }^{*} \mathrm{P}<0.05\right)$

was appreciated that dental surgeons present a higher frequency of genotoxic and cytotoxic damage in comparison to dental technicians, this could be because dentists are exposed to a greater number of agents for a longer time, in addition to being in direct interaction with patients.

\section{Conclusions}

The professions related to dental procedures involve a risk of cytotoxicity or genotoxicity demonstrated by the increased frequency of MNC and NA, phenomena related to cytokinesis and cell death; both as a dental technician and as a dental surgeon, although the latter involves higher risk. The MNC and NA are markers that reflect damage related to an increased risk of cancer, chronic degenerative diseases and premature aging in these populations.

\section{Acknowledgments}

We thank the support to the International Program of Medicine, the Faculties of Medicine and Dentistry of the Universidad Autónoma de Guadalajara.

\section{Declarations}

Conflict of interest: None.

Animal studies: N/A.

\section{References}

1. Zalacain ML, Sierrasesúmaga L, Patiño A (2005) El ensayo de micronúcleos como medida de inestabilidad genética inducida por agentes genotóxicos. Anales del Sistema Sanitario de Navarra 28: 227-236.

2. Schweikl H, Hiller KA, Bolay C, Kreissl M, Kreismann W, et al. (2005) Cytotoxic and mutagenic effects of dental composite materials. Biomaterials 26: 1713-9. [Crossref]

3. Madhyastha PS, Madhyastha PS, Naik DG, Kotian R, Padma D, et al. (2015) Evaluation of cytotoxicity of silorane and methacrylate based dental composites using human gingival fibroblasts. J Clin Diagn Res 9: ZC05-8. [Crossref]

4. Camargo CH, Camargo SE, Valera MC, Hiller KA, Schmalz G, et al. (2009) The induction of cytotoxicity, oxidative stress, and genotoxicity by root canal sealers in mammalian cells. Oral Surg Oral Med Oral Pathol Oral Radiol Endod 108: 952-960. [Crossref]

5. Schweikl H, Hiller KA, Eckhardt A, Bolay C, Spagnuolo G, et al. (2008) Differential gene expression involved in oxidative stress 6 . response caused by triethylene glycol dimethacrylate. Biomaterials 29: 1377-1387. [Crossref]

6. Wegehaupt FJ, Tauböck TT, Attin T, Belibasakis GN (2014) Influence of light-curing mode on the cytotoxicity of resin-based surface sealants. BMC Oral Health 14: 48. [Crossref]

7. Hernández González D, Méndez Silva J, Díaz Caballero A (2014) Efectos genotóxicos de las resinas en odontología: revisión de literatura. Avances en Odontoestomatología 30: 29-38.

8. Dias Ribeiro AP, Sacono NT, Lessa FC, Nogueira I, Coldebella CR, et al. (2009) Cytotoxic effect of a $35 \%$ hydrogen peroxide bleaching gel on odontoblast-like MDPC23 cells. Oral Surg Oral Med Oral Pathol Oral Radiol Endod 108: 458-464. [Crossref] 
9. Wataha JC (2012) Predicting clinical biological responses to dental materials. Dent Mater 28: 23-40. [Crossref]

10. Lorenzoni DC, Cuzzuol Fracalossi AC, Carlin V, Araki Ribeiro D, Sant' Anna EF (2012) Cytogenetic biomonitoring in children submitting to a complete set of radiographs for orthodontic planning. Angle Orthod 82: 585-590. [Crossref]

11. Jara-Ettinger AC, López-Tavera JC, Zavala-Cerna MG, Torres-Bugarín O (2015) Genotoxic evaluation of Mexican welders occupationally exposed to welding-fumes using the micronucleus test on exfoliated oral mucosa cells: A cross-sectional, casecontrol study. PLoSOne 10: e0131548. [Crossref]

12. Torres-Bugarín O, Ramos-Ibarra ML (2013) Utilidad de la Prueba de Micronúcleos y Anormalidades Nucleares en Células Exfoliadas de Mucosa Oral en la Evaluación de Daño Genotóxico y Citotóxico. Inter J Morph 31: 650-657.

13. Erdemir EO, Şengün A, Ulker M (2007) Cytotoxicity of mouthrinses on epithelial cells by micronucleus test. Eur J Dent 1: 80-85. [Crossref]

14. Li N, Sun Z, Han C, Chen J (1999) The chemopreventive effects of tea on human oral precancerous mucosa lesions. Proc Soc Exp Biol Med 220: 218-224. [Crossref]

15. Torres-Bugarín O, Zavala-Cerna MG, Macriz-Romero N, Flores-García A, RamosIbarra ML (2013) Procedimientos básicos de la prueba de micronúcleos y anormalidades nucleares en células exfoliadas de mucosa oral. El Residente 8: 4-11.

16. Koerdt S, Siebers J, Bloch W, Ristow O, Kuebler AC, et al. (2014) Role of oxidative and nitrosative stress in autogenous bone grafts to the mandible using guided bone regeneration and a deproteinized bovine bone material. J Craniomaxillofac Surg 42: 560-567. [Crossref]

17. Zamora-Perez AL, Ortiz-García YM, Lazalde-Ramos BP, Guerrero-Velázquez C, Gómez-Meda BC, et al. (2015) Increased micronuclei and nuclear abnormalities in buccal mucosa and oxidative damage in saliva from patients with chronic and aggressive periodontal diseases. J Periodontal Res 50: 28-36. [Crossref]

18. Arutiunian RM, Tumanian ER, Shirinian GS (1990) An analysis of the micronuclei in the oral mucosa for assessing the cytogenetic effect of environmental pollutant. Tsitol Genet 24: 57-60. [Crossref]

19. Arora P, Devi P, Wazir SS (2014) Evaluation of genotoxicity in patients subjected to panoramic radiography by micronucleus assay on epithelial cells of the oral mucosa. $J$ Dent (Tehran) 11: 47-55. [Crossref]

20. Torres-Bugarin O, De Anda-Casillas A, Ramírez-Muñoz MP, Sánchez-Corona J, Cantú JM, et al. (1998) Determination of diesel genotoxicity in firebreathers by micronuclei and nuclear abnormalities in buccal mucosa. Mutat Res 413: 277-281. [Crossref]

21. Tolbert J PE, Shy MC, Allen JW (1992) Micronuclei and other nuclear anomalies in buccal smears: methods development. Mutat Res 271: 69-77. [Crossref]
22. Tolbert PE, Shy CM, Allen JW (1991) Micronuclei and other nuclear anomalies in buccal smears: a field test in snuff users. Am J Epidemiol 134: 840-850. [Crossref]

23. Thomas P, Holland N, Bolognesi C, Kirsch-Volders M, Bonassi S, et al. (2009) Buccal micronucleus cytome assay. Nat Protoc 4: 825-837. [Crossref]

24. Angelieri F, Carlin V, Saez DM, Pozzi R, Ribeiro DA (2010) Mutagenicity and cytotoxicity assessment in patients undergoing orthodontic radiographs. Dentomaxillofac Radiol 39: 437-440. [Crossref]

25. Nimmo A, Werley MS, Martin JS, Tansy MF (1990) Particulate inhalation during the removal of amalgam restorations. J Prosthet Dent 63: 228-233. [Crossref]

26. Cunha AS, Castillo WO, Takahashi CS, Küchler EC, Segato RAB, et al. (2018) Genotoxic and cytotoxic effects of Haas appliance in exfoliated buccal mucosa cells during orthodontic treatment. Angle Orthod 88: 590-595. [Crossref]

27. Barnes JB, Harrel SK, Rivera-Hidalgo F (1998) Blood contamination of the aerosols produced by in vivo use of ultrasonic scalers. J Periodontol 69: 434-438. [Crossref]

28. Restrepo Ospina DP, Ardila Medina MC (2010) Reacciones adversas ocasionadas por los biomateriales usados en prostodoncia. Avances en Odontoestomatología 26: 19-30.

29. Limberger KM, Westphalen GH, Menezes LM, Medina-Silva R (2011) Cytotoxicity of orthodontic materials assessed by survival tests in Saccharomyces cerevisiae. Dent Mater 27: e81-e86. [Crossref]

30. Fuentes Puebla LS, Torres F, Valencia Fernández V (2015) Efectos biológicos de los Rayo-X en la práctica de Estomatología. Revista Habanera de Ciencias Médicas 14: 337-347.

31. da Fonte JB, Andrade TM, Albuquerque RL Jr, de Melo MFB, Takeshita WM (2018) Evidence of genotoxicity and cytotoxicity of X-rays in the oral mucosa epithelium of adults subjected to cone beam CT. Dentomaxillofac Radiol 47: 20170160. [Crossref]

32. Spagnuolo GM, Annunziata M, Rengo S (2004) Cytotoxicity and oxidative stress caused by dental adhesive systems cured with halogen and LED lights. Clin Oral Investig 8: 81-85. [Crossref]

33. Demirci M, Hiller KA, Bosl C, Galler K, Schmalz G, et al. (2008) The induction of oxidative stress, cytotoxicity, and genotoxicity by dental adhesives. Dent Mater 24 : 362-371. [Crossref]

34. Ogden GR, Cowpe JG, Wight AJ (1997) Oral exfoliative cytology: review of methods of assessment. J Oral Pathol Med 26: 201-205. [Crossref]

35. Nersesian AK, Zil'fian VN, Kumkumadzhian VA, Nersesian AK (1993) An analysis of the micronuclei in the oral mucosa of cancer patients for assessing the clastogenic effect of chemical preparations. Tsitol Genet 27: 77-80. [Crossref]

Copyright: (2019 Daniel MNL. This is an open-access article distributed under the terms of the Creative Commons Attribution License, which permits unrestricted use, distribution, and reproduction in any medium, provided the original author and source are credited. 